\title{
Reducing the risk of lethal encounters: vessels and right whales in the Bay of Fundy and on the Scotian Shelf
}

\author{
Angelia S. M. Vanderlaan ${ }^{1, *}$, Christopher T. Taggart ${ }^{1}$, Anna R. Serdynska ${ }^{1}$, \\ Robert D. Kenney ${ }^{2}$, Moira W. Brown ${ }^{3,4}$ \\ ${ }^{1}$ Department of Oceanography, Dalhousie University, Halifax, Nova Scotia B3H 4J1, Canada \\ ${ }^{2}$ Graduate School of Oceanography, University of Rhode Island, Narragansett, Rhode Island 02882, USA \\ ${ }^{3}$ New England Aquarium, Boston, Massachusetts 02110, USA \\ ${ }^{4}$ Canadian Whale Institute, Box 633, Bolton, Ontario L7E 5T4, Canada
}

\begin{abstract}
The North Atlantic right whale Eubalaena glacialis is endangered, in part, due to vesselstrike mortality. We use vessel traffic and right whale survey data $(\sim 3$ nautical miles [n miles], $\sim 5.6 \mathrm{~km}$ resolution) for the Bay of Fundy and on the Scotian Shelf (northwest Atlantic) to determine the relative risk of lethal vessel encounters by using 2 estimates: (1) the event - the relative probability of a vessel encountering a right whale, and (2) the consequence - the probability of a lethal injury arising from an encounter. For the Bay of Fundy region our estimates demonstrate that the relative risk of lethal collision could be reduced by $62 \%$ by means of an amendment to the traffic separation scheme (TSS) that intersects a Right Whale Conservation Area. In the Roseway Basin region of the Scotian Shelf, the majority of vessels navigate outside of a Right Whale Conservation Area, although the highest relative risk is concentrated within the Conservation Area where fewer vessels navigate at greater speed. Here, our estimates demonstrate that a seasonal recommendatory area to be avoided (ATBA) could be designed to reduce the risk imposed by vessels upon right whales in the region. Our estimates contributed to the International Maritime Organisation (IMO) adoption of a TSS amendment in the Bay of Fundy and an ATBA on the Scotian Shelf. Thus, the goal of achieving the greatest reduction in the risk of lethal vessel-encounters with whales, balanced by some minimal disruption to vessel operations while maintaining safe navigation, can be achieved.
\end{abstract}

KEY WORDS: Right whale $\cdot$ Eubalaena glacialis $\cdot$ Mortality $\cdot$ Vessel $\cdot$ Shipping $\cdot$ Strike $\cdot$ Collision Lethal encounter $\cdot$ Fundy $\cdot$ Roseway

\section{INTRODUCTION}

The North Atlantic right whale Eubalaena glacialis (Rosenbaum et al. 2000), hereafter referred to as right whale, is considered one of the most endangered large whales (Caswell et al. 1999, Kraus et al. 2005) with uncertain population estimates around $300( \pm 10 \%)$ and 350 ind. in the North Atlantic (IWC 2001, Kraus \& Rolland 2007). Recent analyses revealed a marginally increasing growth rate of 1.03 in 1980 that systematically declined to a marginally decreasing rate of 0.98 by 1995 (Fujiwara \& Caswell 2001). Caswell et al.
(1999) estimated extinction probabilities centered on the year 2200 based on contemporary population dynamics. Hypotheses related to species recovery limitations include those associated with reproductive rate (Knowlton et al. 1994, Kraus et al. 2001), genetic variability (Waldick et al. 2002), prey-field dynamics (Kenney et al. 2001, Baumgartner et al. 2007, Michaud \& Taggart 2007), and deleterious human activity (Kraus 1990, Knowlton \& Kraus 2001, Kraus et al. 2005). With approximately one-half of the deaths reported being caused by human activities (Moore et al. 2007) and vessel strikes accounting for $53 \%$ of the determined 
deaths in necroposied whales (Campbell-Malone et al. 2008), we focus our study on the probability of lethal vessel collisions.

The recovery of the right whale is, in part, contingent on a reduction in the number of lethal vessel-strikes (e.g. Caswell et al. 1999, Fujiwara \& Caswell 2001, IWC 2001, Kraus et al. 2005). As the right whale appears on a per capita basis to be more prone to vessel strikes than all other large whales (Vanderlaan \& Taggart 2007), changes to ocean-going vessel operations must be implemented to protect the species (Kraus et al. 2005), particularly in coastal and shelf regions. The 3 primary means of reducing the likelihood of vessels striking right whales include the education of mariners, technological methodologies for detecting whales and warning mariners of whales and warning whales of vessels, and changing typical vessel operations through altered traffic routing and vessel speed restrictions (Knowlton \& Brown 2007).

Technological methods for alerting mariners to the presence of right whales include marine communication relays of whale sightings by and to vessels transiting right whale habitat (Brown et al. 2007). Passive acoustics can be used to monitor and geo-locate right whales (Matthews et al. 2001, Laurinolli et al. 2003, Vanderlaan et al. 2003, Mellinger et al. 2007), and near real-time acoustic monitoring for use in alerting mariners to the presence and location of right whales is becoming a real possibility (Clark et al. 2007). Regardless of the method used, for the transmission of whale locations to mariners to be successful, mariners must be willing and able to safely manoeuvre to avoid potential collisions.

There is little compelling evidence to show that right whales avoid approaching vessels (Vanderlaan \& Taggart 2007, see also Panigada et al. 2006) and whales may be habituated to vessel noise and ignore it (Nowacek et al. 2004). Technological methodologies for alerting whales to the presence of vessels include active acoustic devices (scare tactics). Such devices have been successful in reducing incidental entanglements of harbour porpoises (e.g. Kraus et al. 1997, Trippel et al. 1999, Culik et al. 2001) but we know of no similar results for large baleen whales. When Todd et al. (1992) used such devices to alert humpback Megaptera novaeangliae and minke Balaenoptera acutorostrata whales to the presence of fishing gear, the animals approached closer to gear with active devices than to gear with inactive devices. Nowacek et al. (2004) demonstrated that right whales were not deterred by disharmonic alarm sounds spanning the presumed hearing range of the whales, and the alarm resulted in the whales swimming strongly to the surface, where they were exposed to an increased likelihood of a vessel strike.
The 2 most simple and practical methods of decreasing the likelihood of a vessel strike to a whale are altering vessel traffic routing in and around known whale habitats (to decrease the probability of whale encounter) or reducing vessel speeds (to decrease the probability of a lethal injury in the case of an encounter). Only the vessel re-routing option will reduce the concurrence, both spatially and temporally, of vessels and whales. Only the reduced vessel-speed option will decrease the likelihood of a lethal injury should an encounter occur (cf. Vanderlaan \& Taggart 2007). In combining the bases of the above 2 options a decreased risk (decreased probability of event and decreased consequence, i.e. lethality, if the event occurs) of a lethal collision between a vessel and a whale accrues (Fig. 1).

Right whales are migratory animals and a large proportion of the population occupies 2 primary feeding habitats in the waters of Atlantic Canada during June
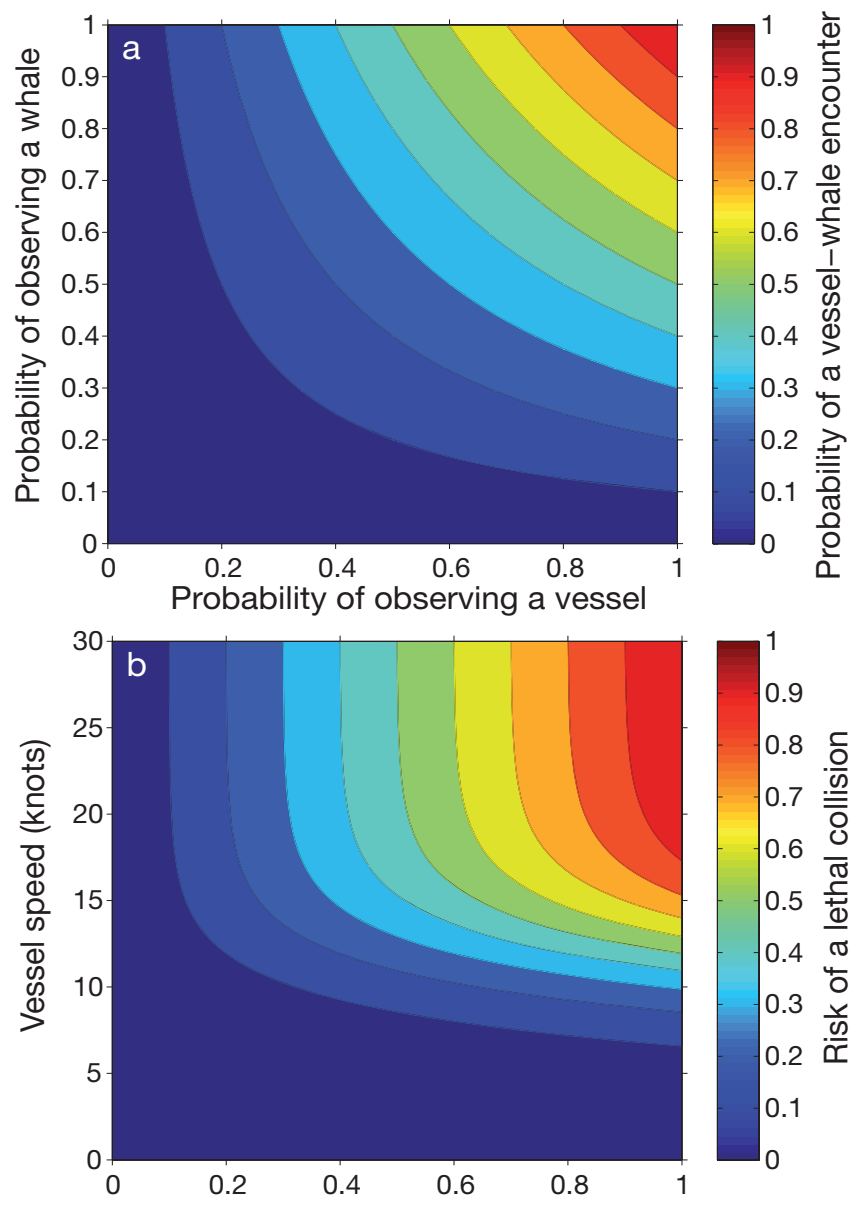

Probability of a vessel-whale encounter

Fig. 1. Nomographs illustrating (a) the generalised 0,1 probability of observing a vessel and a whale at the same time and location, i.e. encounter, and (b) the risk of a lethal collision as a function of speed (from Vanderlaan \& Taggart 2007) given a vessel-whale encounter 
through October (Gaskin 1987, Stone et al. 1988, Brown et al. 1995); the Grand Manan Basin in the Bay of Fundy (hereafter Fundy) and Roseway Basin on the southwest Scotian Shelf (hereafter Roseway). Each habitat encompasses a Canadian Right Whale Conservation Area (Fig. 2) that serves only to warn vessel crews transiting the regions that right whales are likely to be present (Brown et al. 1995). There are no vessel regulations (e.g. routing, speed restrictions) associated with these conservation areas, and actions taken by a vessel crew to minimise a whale-strike, as recommended on nautical charts and notices to mariners (slow down and/or avoid region), would be strictly voluntary (Brown et al. 1995).

In the present study we quantitatively address the problem of vessels striking whales by using vessel traffic and right whale survey and sighting data to determine the relative probability of vessel and right whale encounters at $\sim 3$ nautical mile $(\mathrm{n} \text { mile })^{\mathbf{1}}$ resolution $(\sim 5 \mathrm{~km})$ in the Fundy and Roseway regions. We do so, in part, because the Fundy and Roseway regions are places where aggregations of right whales intersect typical coastal vessel-traffic patterns: self-determined lanes in Roseway, and a formal traffic separation scheme in Fundy. Together with the encounter probability and vessel speed estimates, we employ the Vanderlaan \& Taggart (2007) lethality model to estimate the relative risk of a lethal encounter between a vessel and a right whale in Fundy and Roseway. We then use the results to illustrate how these analyses have (IMO 2003), and will (IMO 2007a,b), be employed as conservation practices to minimise the risk of lethal vessel strikes to right whales.

\section{MATERIALS AND METHODS}

Whale data. An overview of the whale survey methodologies and quality control are provided in Brown et al. (2007), though the salient features are summarised here. Survey platforms were primarily vessels and, secondarily, aircraft that followed systematic survey lines. Observers used standardised methods and vessels travelled at a nominal 12 knots $\left(22 \mathrm{~km} \mathrm{~h}^{-1}\right.$ ) along typically $\mathrm{N}-\mathrm{S}$ survey lines spaced at a nominal $4 \mathrm{n}$ miles $(7.4 \mathrm{~km})$, and data used for analytical purposes were considered valid only when visibility was nominally $\geq 2 \mathrm{n}$ miles $(3.7 \mathrm{~km})$ and in sea state nominally $<4$ (Beaufort wind force scale). All right whales were counted and their locations geo-referenced. Aerial surveys were conducted as above

${ }^{1}$ We use knots and nautical mile (n mile) units as they reflect the nautical convention, and we provide SI equivalents

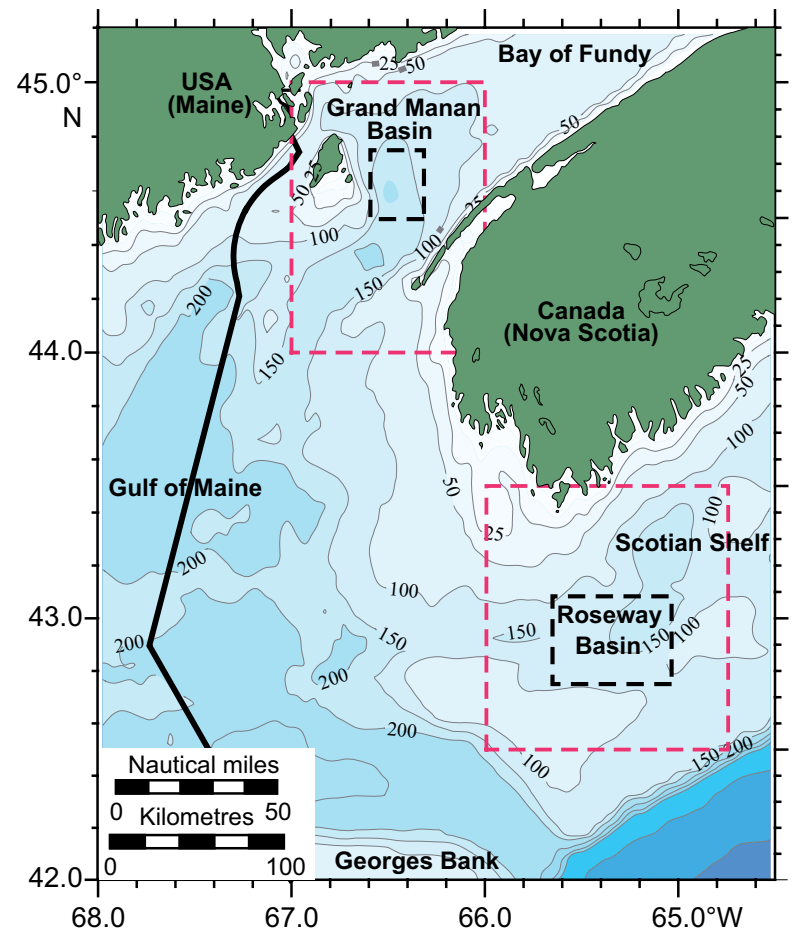

Fig. 2. Bathymetric $(\mathrm{m})$ chart illustrating the Gulf of Maine, the Canada Exclusive Economic Zone limit (thick black line), and the Grand Manan (Bay of Fundy) and Roseway (western Scotian Shelf) basin study domains (red dashed line) that encompass the Canadian Right Whale Conservation Areas (black dashed line)

using a Cessna ${ }^{\circledR} 337$ Skymaster ${ }^{\circledR}$ flying at a nominal 100 knots $\left(185 \mathrm{~km} \mathrm{~h}^{-1}\right)$ at $230 \mathrm{~m}$ altitude along E-W survey lines spaced at nominally $5 \mathrm{n}$ mile $(9.3 \mathrm{~km})$ intervals (see also Scott \& Gilbert 1982, CETAP 1982).

Quality controlled right whale sightings per unit effort (SPUE, number of whales observed per $1000 \mathrm{~km}$ of the standardised survey track) data, collected during surveys described above for the period 1987 through 2000, were provided for each of the Fundy and Roseway regions (no survey data for 1993, 1994, 1996, 1998 in the latter) by the North Atlantic Right Whale Consortium (NARWC 2005; see also Kenney 2001). We aggregated the annual data, as annual SPUE estimates are too limited in time and space in any given year. The whale data were then resolved to represent cellspecific SPUE estimates across the standard NARWC $20 \times 20$-cell (Fundy; area $=2520 \mathrm{n} \mathrm{miles}{ }^{2}, 8643 \mathrm{~km}^{2}$ ) and $25 \times 20$-cell (Roseway; area $=3300 \mathrm{n} \mathrm{miles}{ }^{2}$, $11319 \mathrm{~km}^{2}$ ) grids with each cell defined by 3' N latitude and $3^{\prime} \mathrm{W}$ longitude; i.e. $3 \mathrm{n}$ miles $(5.6 \mathrm{~km}) \mathrm{N}-\mathrm{S}$ and $\sim 2.1 \mathrm{n}$ miles $(3.9 \mathrm{~km}$, Fundy) and $\sim 2.2 \mathrm{n}$ miles (4.1 km, Roseway) E-W. This is the limiting resolution used for all analyses presented below.

Survey effort is not uniform across either of the regional grids, and our calculations based on the SPUE 
data disregard biases that may be associated with the geographic distribution of effort. One grid-cell in the Roseway grid had an anomalously high SPUE value (2626), representing a near 4 -fold increase over the next highest value. In comparison to the frequency distribution of all non-zero SPUE estimates $(\mathrm{n}=66)$ over the grid, the value 2626 is $\sim 16$-fold greater than the inter-quartile range, was considered an extreme outlier, and was replaced by the overall grid-cell mean SPUE estimate (excluding the outlier) of 22.4.

Vessel traffic: Bay of Fundy. Vessel-tracking radar data for the period 9 June through 31 October 2000 in Fundy were extracted from the Kongsberg Norcontrol IT $^{\circledR}$ Vessel Traffic Management and Information System computerised log-files stored with the Marine Communication and Traffic Services (MCTS) Saint John, New Brunswick, Canada. Each data record contains various fields that include 'rule-vessel' (those $\geq 20 \mathrm{~m}$ in overall length and $\geq 300$ gross registered tonnage, GRT; Canada Shipping Act 1985) identity, location (latitude and longitude), date, time, and speed (knots) logged at $2.50 \times 10^{-3} \mathrm{~Hz}$. Only those vessel data that fell within the domain of the NARWC survey grid were used. There were some periods within some days when tracking data were not logged ( $\min$ to $\mathrm{h}$ ). There were no data available for the entirety of 27 June. There were no data for the period 05 through $22 \mathrm{Au}$ gust 2000 and thus the entire August 2000 dataset was replaced by the entire August 2001 dataset. We assume that the few missing data and the replacement data do not unduly compromise the analyses. This assumption, for the August data, was validated through an analysis of day-to-day rule-vessel movements (Transport Canada data) at major ports in the Bay of Fundy over the period 2000 through 2002 inclusive.

'Non-rule' vessel-targets (e.g. fishing boats, pleasure craft, unidentified objects etc.) are also tracked periodically and at the discretion of MCTS controllers, and such radar data were ignored in our analyses due to the paucity of systematic data logging. MCTS controllers assign rule-vessel names (identifiers) at their discretion and thus there are many aliases for a given unique rule-vessel among the records. Accordingly, extensive efforts to quality control and error-check were made to ensure all aliases were identified and assigned to the appropriate 'unique' vessel. There were instances when the same apparently unique vessel was located in 2 different places at the same time; in such cases the data were retained because each vessel was identified as a rule vessel (though of unknown identity).

Data extraction and assignment of vessel data to the appropriate NARWC grid-cell was relatively straightforward. However, adjustments were required when (1) a vessel appeared to 'skip' one or more non-adjoin- ing grid-cells because it did not occupy the cell(s) at the time the record was logged, or (2) a vessel had an incomplete (partially missing) track over an extended period because there were no records (thus no track) for the extended period. In either case, the vessel track and associated data were interpolated (Euclidean) across adjoining grid-cells. Unique-vessel tracking algorithms were developed for quality control, and where quality norms based on location, time and speed evolution comparisons were not met, a graphical procedure was employed to achieve the required interpolation; otherwise the data were discarded. For example, some uniquely identified vessels appeared at more or less random locations in time for which no rational interpretation or interpolation could be inferred; such data were rare and were discarded. For the most part, ill-behaved vessel data were attributable to 'non-rule' vessels.

All vessel data (identity, number, speed etc.) were then aggregated on a daily $(24 \mathrm{~h})$ basis across the 400 grid-cell domain and thus spatially resolved as above for the SPUE data. This procedure provided the number of vessels transiting the cell and the weighted mean (by unique vessel) vessel speed within the cell. Some unique vessels entered a given cell more than once within a $24 \mathrm{~h}$ period (return trips, backtracking) and they were statistically treated as new observations. There were extremely rare occasions when a rule vessel entered a grid-cell more than 20 times within a day (typically research or coast-guard vessels), and only the first 20 entries were used. For the purposes of this study, the daily statistics were then aggregated through time, to estimate the total number of vessels and mean speed per grid-cell for June through October. The mean-speed estimates for 4 grid cells (each with a land-water interface) were determined to be statistical outliers (possibly related to land-water-vessel radar reflection effects) and these speed estimates (not vessel numbers) were excluded from analyses.

The Bay of Fundy Traffic Separation Scheme (TSS) spatially separates inbound and outbound rule-vessels entering and departing the Bay (see Fig. 3). The International Maritime Organisation (IMO) adopted amendments to the existing TSS and they were implemented on 01 July 2003 (IMO 2003). In the following we refer to the pre-amendment TSS as the 'original' and the post-amendment TSS as the 'amended'.

Vessel traffic: Roseway Basin. Roseway vessel traffic data for 1989 to 2002 inclusive were available from the Eastern Canada Vessel Traffic Services Zone Regulations (ECAREG; Canada Shipping Act 1985) database and from the International Comprehensive Ocean-Atmosphere Data Set (ICOADS, National Center for Atmospheric Research [NCAR], Boulder, Colorado). 
ECAREG is a mandatory reporting system that requires vessels ( $\geq 500$ GRT or carrying pollutants or dangerous cargo) to report (call in) $24 \mathrm{~h}$ prior to entering an ECAREG zone (all Canadian waters south of $60^{\circ} \mathrm{N}$ and the St Lawrence River east of $66^{\circ} \mathrm{W}$ ) and $2 \mathrm{~h}$ prior to departing a Canadian port in an ECAREG zone. Vessels report to ECAREG more frequently than required. ICOADS is derived from the fleet of Voluntary Observing Ships and represents $~ 9 \%$ of the world commercial fleet (Corbett \& Koehler 2003, Corbett 2004). The ECAREG data (exact location at reporting of unique vessels) were quality controlled for errors, such as impossible dates, locations, speeds, and tonnages, and errors were treated as missing values. ICOADS data (unique vessels resolved to $6^{\prime}$ grid-cells) are quality controlled at NCAR, with errors treated as missing values. The ECAREG and ICOADS records were extracted and assigned to a large $32 \times 306^{\prime}$ grid (centred on the centre of the NARWC $25 \times 20$-cell Roseway 3' grid) and summed to provide the total number of vessels reporting (vessel count) in each 6' grid-cell. The mean speed of vessels within each grid-cell was calculated based on the ECAREG reported speeds and the mid-point of each $5 \mathrm{knot}\left(9.3 \mathrm{~km} \mathrm{~h}^{-1}\right)$ speed-class interval provided by ICOADS. The vessel data resolved at $6^{\prime}$ were then smoothed using a spline function (Surfer ${ }^{\circledR}$ ver.8; 2002 Golden Software) to resolve the data at 3'. Only those data encompassed by the NARWC $25 \times 20$ cell 3' grid were used in the analyses.

For both ECAREG and ICOADS, the vessel data represent only those vessels that reported within the above-specified 3'-grid domain and not the total number of vessels that transit the domain. However, the extent of the data (1989 through 2002) for both sets of data is sufficient to provide statistically reliable estimates of the spatial distribution of vessel traffic and vessel speeds.

Estimating relative probability of encounter. We assume the 1987 to 2000 aggregate SPUE estimate $\left(S P U E_{i}\right)$ provides the best estimate of the relative probability, at 3' resolution, that a whale occupies a gridcell $i$ relative to other cells in a domain of $n$ cells (simplification of the 2-dimensional $n_{x, y}$ grid) and is calculated as:

$$
P_{\text {rel }}(\text { Whale })_{i}=\frac{\text { SPUE }_{i}}{\sum_{i=1}^{n} \mathrm{SPUE}_{i}}
$$

Similarly, the relative probability that a vessel occupies a grid-cell $i$ relative to other cells in a domain of $n$ cells is calculated as:

$$
P_{\text {rel }}(\text { Vessel })_{i}=\frac{V_{i}}{\sum_{i=1}^{n} V_{i}}
$$

where $V_{i}$ is the aggregate vessel number occupying grid-cell $i$.

Using Eqs. (1) \& (2), the relative probability that a vessel and whale will occupy (encounter each other within) a given grid-cell $i$ is then calculated:

$$
P_{\text {rel }}(\text { Encounter })_{i}=\frac{P_{\text {rel }}(\text { Whale })_{i} \times P_{\text {rel }}(\text { Vessel })_{i}}{\sum_{i=1}^{n}\left(P_{\text {rel }}(\text { Whale })_{i} \times P_{\text {rel }}(\text { Vessel })_{i}\right)}(3)
$$

where the $P_{\text {rel }}$ (Encounter $)_{i}$ estimates are normalised, such that their sum across the grid is equal to 1 .

The $P_{\text {rel }}$ (Encounter) $)_{i}$ estimates in Fundy before and after the TSS amendment were compared by using Eq. (4) below and by 'moving' those vessels transiting the original lanes into the amended lanes. This was achieved by identifying any vessel transiting an original lane, determining its longitudinal location and adjusting that location to place the vessel in the appropriate amended lane at the same relative distance from the western boundary of the lane. The longitudinal locations of those vessels that exited or entered the original TSS to and from ports in Maine and southern New Brunswick were adjusted as above and their routes were interpolated to allow such vessels to enter and exit the 'turnout lanes' (implemented under the TSS amendment; see Fig. 4b) after which their routes were interpolated across the grid to their originating or terminating locations.

To compare relative encounter probabilities before and after the TSS amendment in Fundy and between the Fundy and Roseway regions, Eq. (3) is modified to:

$$
P_{\text {rel }}(\text { Encounter })_{i}=\frac{P_{\text {rel }}(\text { Whale })_{i} \times P_{\text {rel }}(\text { Vessel })_{i}}{\sum_{i=1}^{m}\left(P_{\text {rel }}(\text { Whale })_{i} \times P_{\text {rel }}(\text { Vessel })_{i}\right)}(4)
$$

where $m=\left(n_{\text {original }}+n_{\text {amended }}\right)$ or $m=\left(n_{\text {Fundy }}+n_{\text {Roseway }}\right)$, respectively.

Estimating relative risk. Using the model provided in Vanderlaan \& Taggart (2007) and the mean vessel speed within a grid-cell, the probability of a lethal injury (given encounter) is estimated for both regions. We then quantify the relative risk $\left(\mathrm{RR}_{i}\right)$, at 3 ' resolution, of vessels to right whales based on the event: the relative probability of a vessel encountering a whale (Eq. 3) and the consequence: the probability that the encounter is lethal:

$$
P(\text { Lethal IEncounter })_{i}=\frac{1}{1+\exp ^{-\left(-4.89+0.41 \bar{x}_{i}\right)}}
$$

where $\bar{X}_{i}$ is the mean vessel speed (knots) in grid-cell $i$. Thus, the relative risk becomes:

$$
\mathrm{RR}_{i}=P_{\text {rel }}(\text { Encounter })_{i} \times P(\text { Lethal } \mid \text { Encounter })_{i}
$$

Spatial distribution data (e.g. $P_{\text {rel }}$ (Whale), $P_{\text {rel }}$ (Vessel), $P_{\text {rel }}$ (Encounter), RR etc.) are presented as objec- 
tive contours (Surfer ${ }^{\circledR}$, ver.8; 2002 Golden Software) that rely primarily on kriging and natural neighbour algorithms. All chart figures are equidistance cylindrical projection. All statistical uncertainties are presented as \pm 1 standard error.

\section{RESULTS}

\section{Right whales in the Bay of Fundy}

Based on the NARWC grid domain, there is an overall $67 \%$ chance of observing a right whale within the Grand Manan Basin region that is encompassed by the Right Whale Conservation Area - an estimate that corresponds to a mean relative probability of $0.023 \pm$ 0.0029 that is, on average, $\sim 36$-fold greater than elsewhere in the domain (Fig. 3a). There is a second and smaller area of slightly elevated relative probability north of the Conservation Area and it is bounded to the north by the $100 \mathrm{~m}$ isobath. There is another and larger elevated relative probability immediately south of the Conservation Area, possibly reflecting ingress and egress of the whales to and from the Grand Manan Basin region.

\section{Vessels in the Bay of Fundy}

A total of 768 unique rule-vessels were identified within the MCTS data. A further 759 vessel identities were variants (aliases) of identifiable rule vessels that were corrected to their unique identities. Of these unique vessels, a total of 42 were included in the analyses despite being identified as being in 2 different places as the same time. Thus, the analyses are based on a total of 1485 rule vessels, many of which made several trips through the study domain during the June through October period. There were at least 2622 unidentified, non-rule, vessel-targets that were excluded from our analyses.

The average number of rule vessels grid-cell ${ }^{-1} \mathrm{~d}^{-1}$ in the Fundy domain was $0.37 \pm 0.028$. The grid-cellaveraged number of vessels within the inbound and outbound lanes of the original TSS was $1.1 \pm 0.076$ vessels cell ${ }^{-1} \mathrm{~d}^{-1}$. Approximately $71 \%$ of all rule vessels were transiting the TSS-lanes resulting in a mean $P_{\text {rel }}\left(\right.$ Vessel) of $0.0072 \pm 5.2 \times 10^{-4}$ within the TSS-lanes (Fig. 3b). The remaining $29 \%$ were navigating elsewhere within the domain. The mean $P_{\text {rel }}\left(\right.$ Vessel) outside the TSS-lanes was $9.7 \times 10^{-4} \pm$ $7.2 \times 10^{-5}$; i.e. rule vessels were on average 7.4 -fold more likely to be within the TSS-lanes than not. Approximately $18 \%\left(454 \mathrm{n} \mathrm{mile}{ }^{2}, 1556 \mathrm{~km}^{2}\right)$ of the Fundy domain was unoccupied by a rule vessel over the study period. The elevated $P_{\text {rel }}($ Vessel) in both the inbound and outbound lanes of the original TSS, where it bends from NE to NNE just south of the Conservation Area (the 3A and 3B MCTS call-in locations), reflects a traffic node where vessels enter the lanes from the NW (coastal Maine and southern New Brunswick) and from the ENE (north shore of Nova Scotia).

\section{Relative probability of a vessel encountering a right whale in the Bay of Fundy}

It is clear, and not surprising, that the highest relative probability of a vessel encountering a right whale, on the basis of aggregated vessel number, is located in the NE sector of the Grand Manan Basin and in the Conservation Area where it is intersected by the outbound lane of the original TSS (Fig. 3c). There are also elevated relative encounter probabilities to the NNE and S of the Conservation Areareflecting the whale distributions (Fig. 3a), given the relatively uniform distribution of vessels in the TSSlanes (Fig. 3b).

\section{Vessel speed in the Bay of Fundy}

The mean and median speeds of rule vessels in the Fundy domain during the study period were $\sim 12$ knots $\left(\sim 22 \mathrm{~km} \mathrm{~h}^{-1}\right)$ and $\sim 11$ knots $\left(\sim 20 \mathrm{~km} \mathrm{~h}^{-1}\right)$ respectively (Table 1 ). Vessel speeds were greatest SW of the seaward entrance to the original TSS and remain relatively high (in excess of 14 knots, $26 \mathrm{~km} \mathrm{~h}^{-1}$ ) where the TSS intersects the Right Whale Conservation Area (Fig. 3d). There is no clear evidence that vessels reduce speed when navigating through the Conservation Area, as recommended on nautical charts.

Table 1. Summary vessel speed (in knots, with speed in $\mathrm{km} \mathrm{h}^{-1}$ in parentheses) statistics across the $3^{\prime}$ grid-cell domains in the Bay of Fundy (based on radar data) and Roseway Basin (based on Eastern Canada Vessel Traffic Services Zone Regulations, ECAREG, and International Comprehensive Ocean-Atmosphere Data Set, ICOADS data). $\mathrm{n}=$ no. of grid-cells occupied by vessels

\begin{tabular}{|lcc|}
\hline Statistic & Bay of Fundy & Roseway Basin \\
\hline $\mathrm{n}$ & 329 & 500 \\
Mean & $11.6(21.5)$ & $11.2(20.7)$ \\
Standard deviation & $3.12(5.78)$ & $1.5(2.8)$ \\
Minimum & $0.614(1.14)$ & $7.0(13.0)$ \\
Median & $11.3(20.9)$ & $10.9(20.2)$ \\
Maximum & $24.5(45.4)$ & $15.3(28.3)$ \\
\hline
\end{tabular}



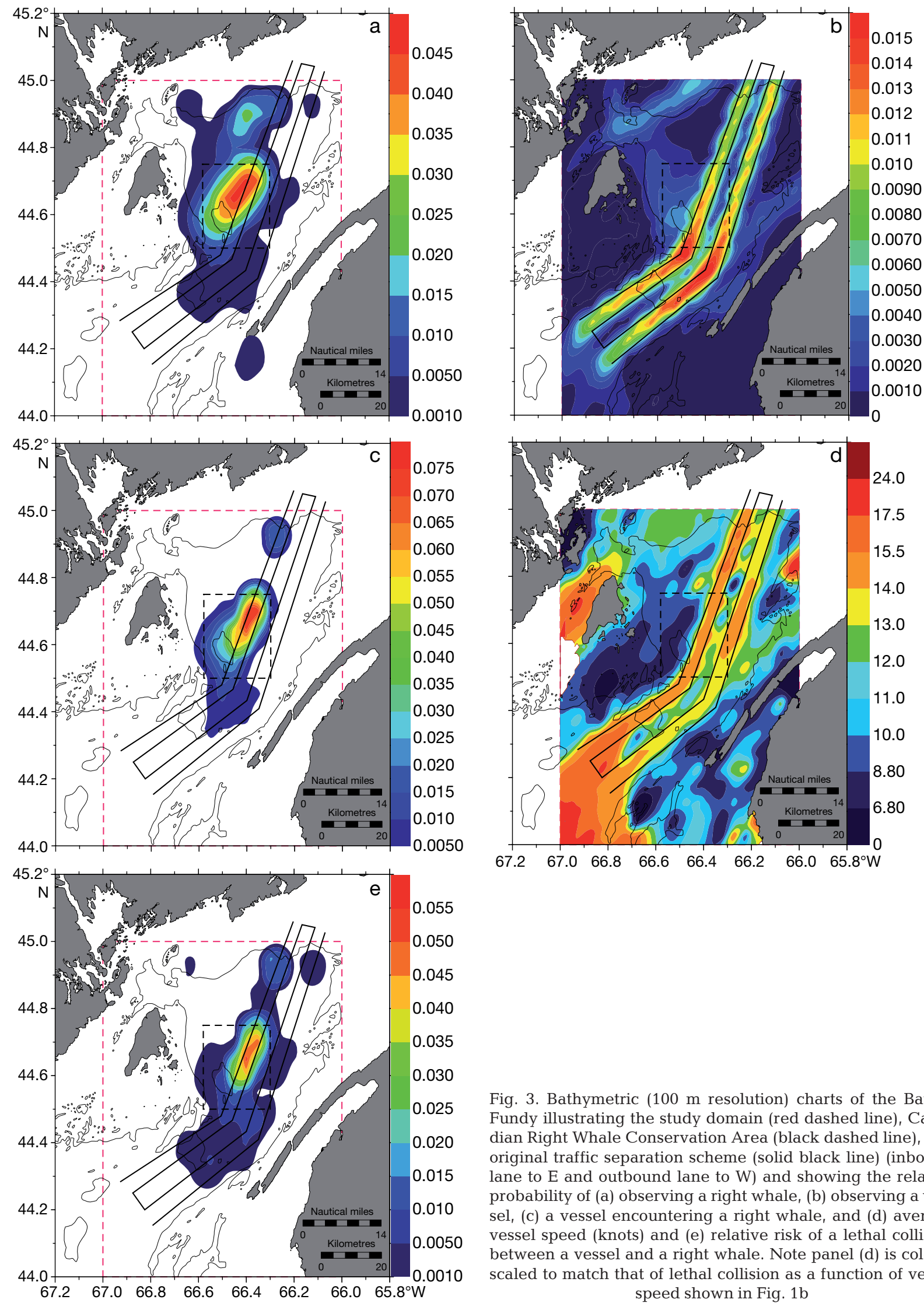

$\begin{array}{llllllll}67.2 & 67.0 & 66.8 & 66.6 & 66.4 & 66.2 & 66.0 & 65.8^{\circ} \mathrm{W}\end{array}$

Fig. 3. Bathymetric (100 $\mathrm{m}$ resolution) charts of the Bay of Fundy illustrating the study domain (red dashed line), Canadian Right Whale Conservation Area (black dashed line), and original traffic separation scheme (solid black line) (inbound lane to $\mathrm{E}$ and outbound lane to $\mathrm{W}$ ) and showing the relative probability of (a) observing a right whale, (b) observing a vessel, (c) a vessel encountering a right whale, and (d) average vessel speed (knots) and (e) relative risk of a lethal collision between a vessel and a right whale. Note panel (d) is colourscaled to match that of lethal collision as a function of vessel speed shown in Fig. 1b 
From the above, it becomes apparent that when the concentration of vessels in the original TSS-lanes (Fig. 3b) is coupled with the vessel-speed estimates (Fig. 3d) the greatest risk to the right whales is expected to be in that part of the Conservation Area associated with elevated SPUE estimates (Fig. 3a).

\section{Probability of a lethal injury and relative risk in the Bay of Fundy}

When the probability-of-lethal-injury model (Vanderlaan \& Taggart 2007) is applied to the spatial estimates of vessel speeds, we estimate an average $P$ (LethallEncounter) of 0.64 within the original TSS-lanes of the Bay of Fundy; i.e. if a whale was struck within the original TSS-lanes there is a $64 \%$ chance, on average, that it would be killed. This probability increases as vessels increase their speed near the seaward end of the TSS (Fig. 3d). If a whale is struck in the area between the coast of Maine and Grand Manan Island, New Brunswick, the probability of a lethal injury is also relatively high with $P$ (LethallEncounter) ranging from 0.72 to 0.84 .

The average relative risk to a right whale from vessels travelling through the original TSS-lanes is 0.0057 (Fig. 3e). This estimate represents a 27 -fold increase in the average probability of a whale being struck and killed in the TSS-lanes over anywhere else in the grid domain. The average relative risk to right whales found only in the portion of the Conservation Area intersected by the outbound lane of the original TSS outbound lane is 270 -fold greater than elsewhere in the domain.

\section{TSS amendment in the Bay of Fundy}

The overall relative probability of a vessel encountering a right whale in the Fundy grid domain with the original TSS decreases by $44 \%$ with the amended TSS. For those 5 grid-cells within the outbound lane of the original TSS that intersects the Right Whale Conservation Area, there is an average reduction of $90 \% \pm 4.2$ in the relative encounter probability associated with the amendment. The mean relative probability of encounter over the entire TSS-lanes decreased by $\sim 40 \%$ (from $0.0080 \pm 0.0019$ to $0.0049 \pm 0.00098$ ) with the TSS amendment. The standardised overall relative risk to right whales of a lethal vessel-strike in the Fundy domain decreased by $62 \%$ with the TSS amendment (Fig. 4). The average relative risk to the whales over the entire TSS-lanes also decreased by $\sim 40 \%$ (from $0.0057 \pm 0.0015$ to $0.0034 \pm 7.3 \times$ $10^{-4}$ ) with the amendment. For those 5 grid-cells within the outbound lane of the original TSS that intersected the Right Whale Conservation Area, there was an average reduction of $90 \% \pm 4.7$ in risk with the amendment.
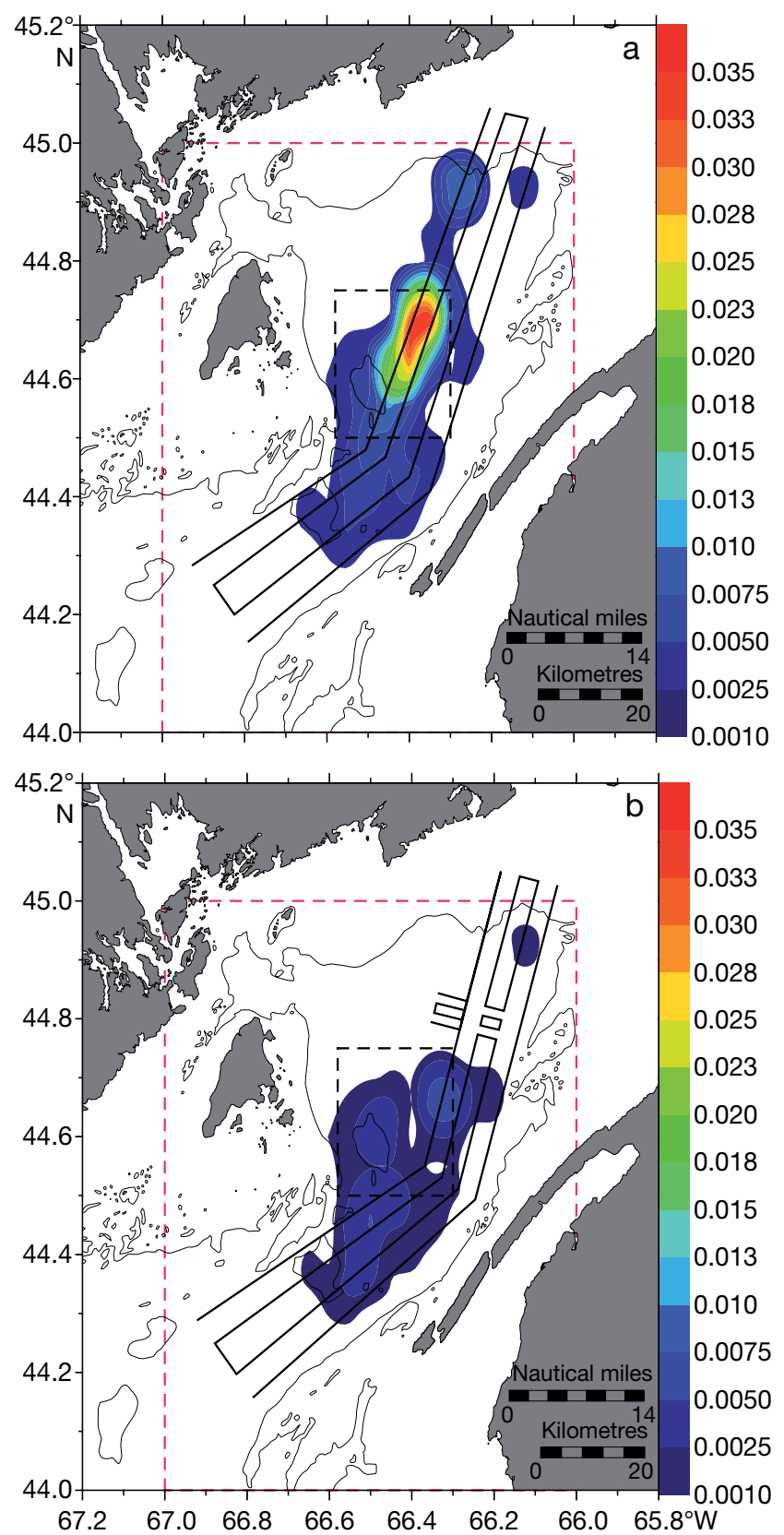

Fig. 4. Bathymetric (100 m resolution) chart of the Bay of Fundy illustrating the study domain (red dashed line), Canadian Right Whale Conservation Area (black dashed line), the original (a) and amended (b) traffic separation schemes (solid black line) and their associated standardised (comparable scale) relative risk of a lethal collision between a vessel and a right whale

\section{Right whales in Roseway Basin}

Based on the NARWC grid domain, there is an overall $86 \%$ chance of observing a right whale within the Roseway Basin Right Whale Conservation Areaan estimate that corresponds to a mean relative prob- 

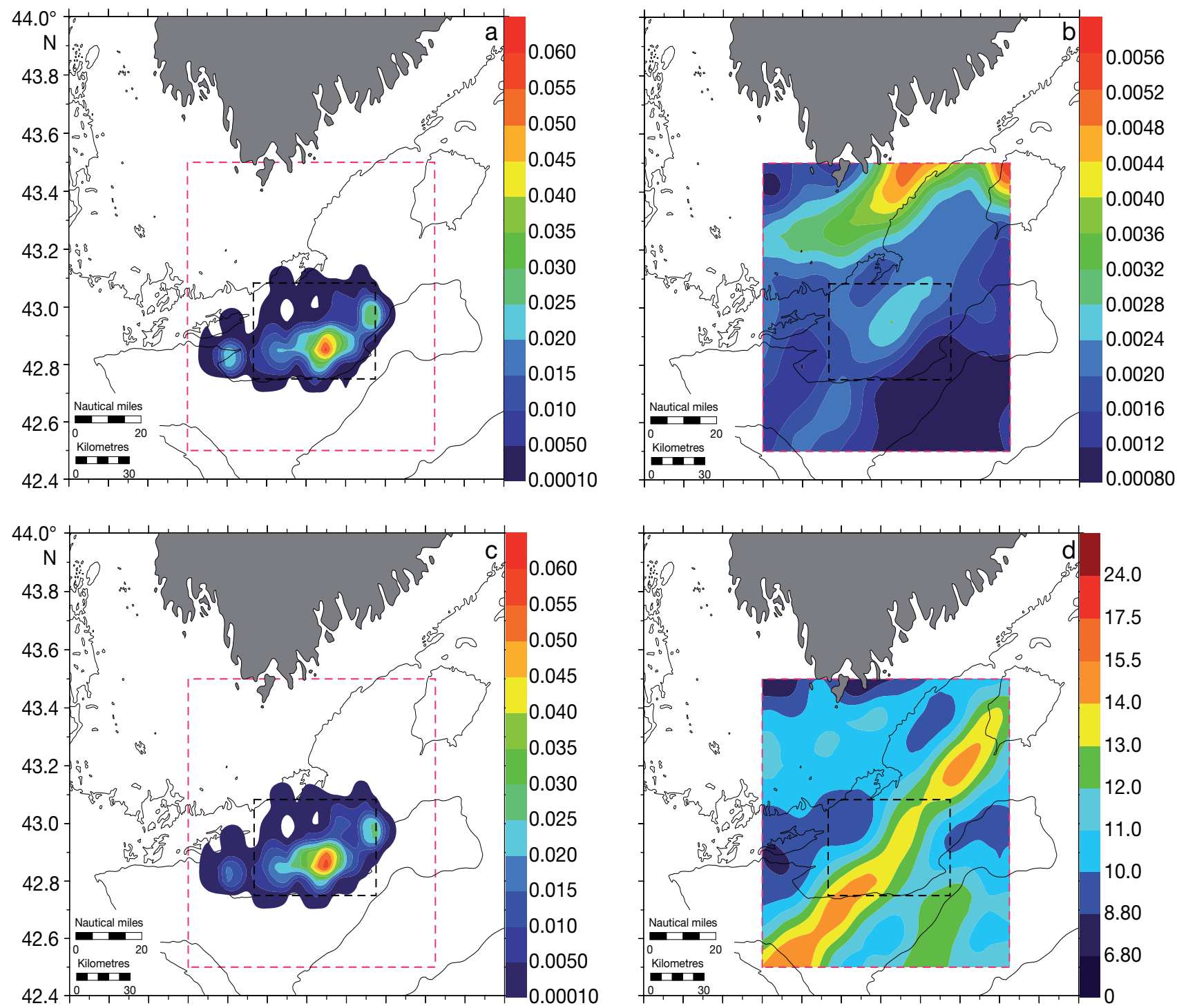

$66.666 .466 .266 .065 .865 .665 .465 .265 .064 .864 .664 .4^{\circ} \mathrm{W}$

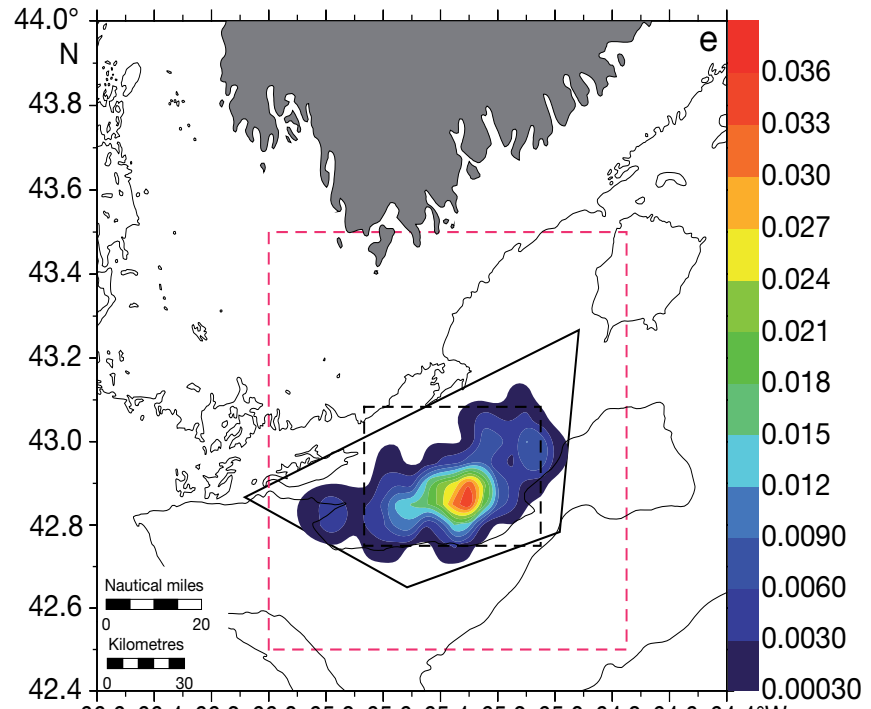

$66.666 .466 .266 .065 .865 .665 .465 .265 .064 .864 .664 .4^{\circ} \mathrm{W}$
Fig. 5. Bathymetric (100 m resolution) chart of the Roseway Basin region illustrating the study domain (red dashed line), Canadian Right Whale Conservation Area (black dashed line), and showing the relative probability of (a) observing a right whale, (b) observing a vessel, (c) a vessel encountering a right whale, and (d) average vessel speed (knots) and (e) relative risk of a lethal collision between a vessel and a right whale. The recommendatory area to be avoided is outlined (solid black line). Note panel (d) is colour-scaled to match that of lethal collision as a function of vessel speed shown in Fig. 1b 
ability of $0.010 \pm 0.0017$ that is on average $\sim 26$-fold greater than elsewhere in the domain (Fig. 5a). The highest relative probability of observing a right whale in the Basin occurs in the south-central region of the Conservation Area $\left(P_{\text {rel }}(\right.$ Whale $\left.)=0.0707\right)$. There are also small regions of elevated probability to the $\mathrm{E}$ and to the $\mathrm{W}$.

\section{Vessels in Roseway Basin}

There were 5374 ECAREG call-in locations in the Roseway domain over the 1989-2002 period, representing 501 unique vessels based on the Lloyd's Register number and an additional 605 records where the Lloyd's number was either not reported or not recorded. Over the same period, there were 3877 ICOADS vessel-call-in locations in the domain, representing 466 unique vessels based on call sign and an additional 10 records where the call sign was not reported or not recorded. The unidentified vessels in either data set were included in the analyses and when the combined data were re-resolved to 3' there were a total of 9036 call-in locations in the domain over the study period ( $2 \%$ loss in re-resolving).

The mean relative probability of observing a vessel in the domain, $P_{\text {rel }}\left(\right.$ Vessel), is $0.0020 \pm 3.8 \times 10^{-5}$ (Fig. 5b). The most concentrated vessel traffic in the region $\left(P_{\text {rel }}(\right.$ Vessel $\left.) \approx 0.0050\right)$ is located north of the Conservation Area. Elsewhere in the domain $P_{\text {rel }}(V e s-$ sel) ranged from 0.0014 to 0.0023 (1st to 3rd quartile). An emergent diagonal traffic pattern associated with an elevated $P_{\text {rel }}($ Vessel $) \approx 0.0025$ intersects the Right Whale Conservation Area in a NE $\leftrightarrow \mathrm{SW}$ direction and indicates that few vessels navigating $\mathrm{NE} \leftrightarrow \mathrm{SW}$ avoid the Conservation Area, as recommended on nautical charts.

\section{Relative probability of a vessel encountering a right whale in Roseway Basin}

In comparison to the Conservation Area in Fundy, the relatively uniform distribution of vessel traffic in the Roseway Basin Conservation Area (Fig. 5b) results in the relative encounter probabilities between a vessel and right whale (Fig. 5c) generally reflecting the relative probability of observing a whale (Fig. 5a); i.e. the highest relative probability of a vessel encountering a right whale is where the highest probability of a observing a whale is located. The mean relative probability of a vessel encountering a right whale is 36 times higher within the Conservation Area than it is for the study domain outside the Conservation Area.

\section{Vessel speed in Roseway Basin}

The mean and median speeds of rule vessels across the Roseway domain during the study period are both $\sim 11$ knots $\left(21 \mathrm{~km} \mathrm{~h}^{-1}\right)$ with a maximum grid-cell mean speed of 15 knots $\left(28 \mathrm{~km} \mathrm{~h}^{-1}\right.$; Table 1$)$. The spatial distribution of the average vessel speeds across the grid is similar to the spatial distribution of vessels (Fig. 5d). However, the diagonal traffic pattern that intersects the Right Whale Conservation Area is associated with vessels navigating at greater speeds (13 to 15 knots: 20 to $28 \mathrm{~km} \mathrm{~h}^{-1}$ ) than vessels to the north where they are most concentrated and are generally navigating at speeds of 10 to 11 knots ( 19 to $20 \mathrm{~km} \mathrm{~h}^{-1}$ ). There is no clear evidence that vessels reduce speed when navigating through the Conservation Area, as recommended on nautical charts.

\section{Probability of a lethal injury and relative risk in Roseway Basin}

The probability of a lethal vessel-strike (arising from an encounter) to a right whale in the Roseway domain ranges from 0.12 to 0.80 , with an overall mean probability of $0.43 \pm 0.0064$. The average probability of a lethal injury within the Right Whale Conservation Area is marginally higher at $0.49 \pm 0.016$. The mean relative risk to right whales from vessels over the entire Roseway domain is $0.0012 \pm 2.4 \times 10^{-4}$ (Fig. 5e). Due to the aggregation of right whales within the Conservation Area and the intersecting traffic navigating at relatively high speed, the mean relative risk is $\sim 68$ times higher at $0.0060 \pm 0.0011$.

\section{DISCUSSION}

The greatest probability of observing a North Atlantic right whale occurs within the Canadian Right Whale Conservation Areas in each of the Grand Manan and Roseway basins. It is within these areas that vessels pose the greatest risk to right whales. In each conservation area the whales are exposed to vessels navigating at speeds near to, or in excess of 13 knots $\left(24 \mathrm{~km} \mathrm{~h}^{-1}\right)$, corresponding to a $P$ (Lethall Encounter) of at least 0.6. For the Bay of Fundy we have shown that the 2003 TSS amendment decreased the overall probability of a vessel encountering a right whale by $44 \%$ and the overall risk by $62 \%$, and these estimates include reductions achieved through the use of the 'turn-out' lanes just north of the Conservation Area (Fig. 6a). In the region where the outbound lane of the original TSS intersected the highest expected concentrations of right whales, the TSS amendment 

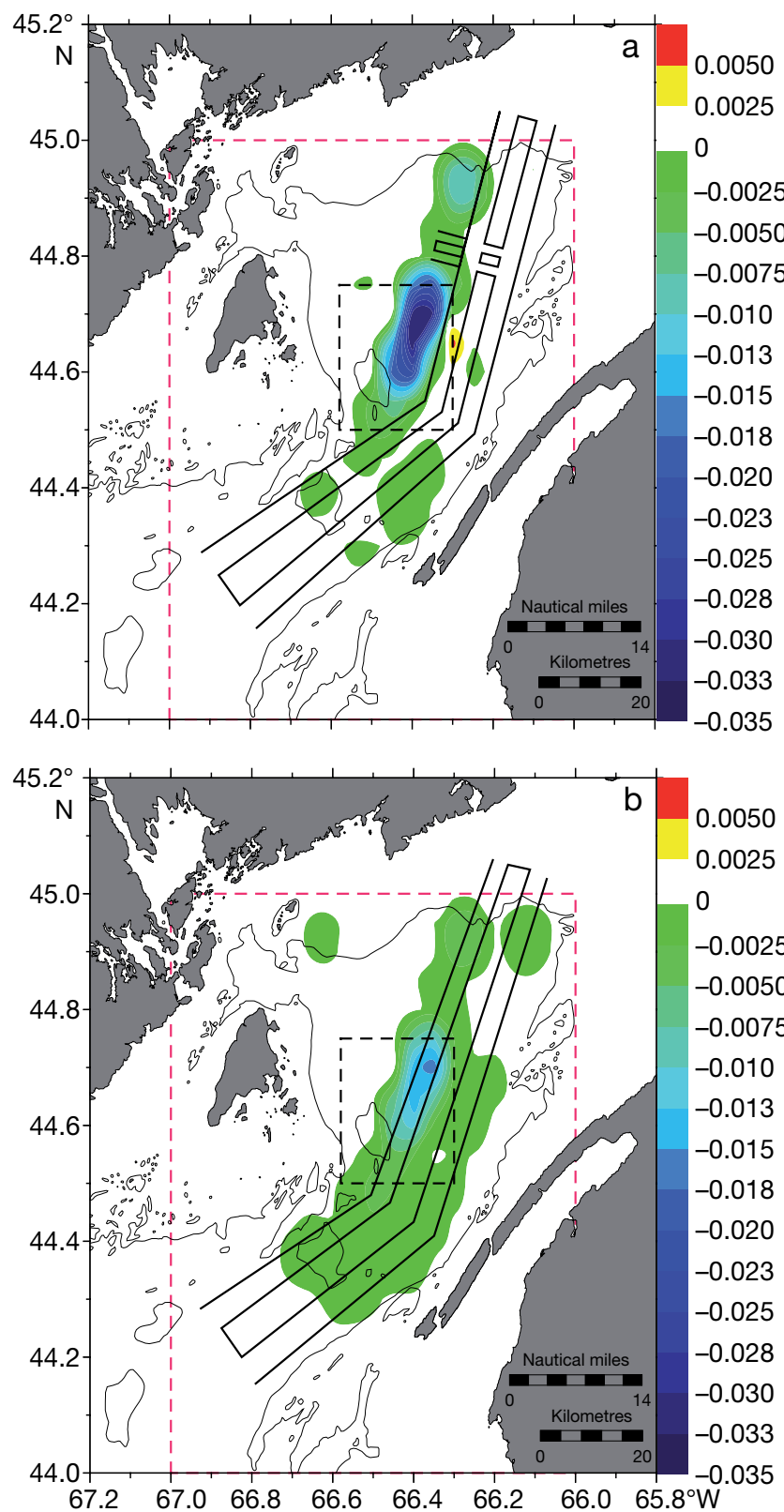

Fig. 6. Bathymetric (100 m resolution) charts of the Bay of Fundy illustrating the study domain (red dashed line), Canadian Right Whale Conservation Area (black dashed line) and the standardised (comparable scale) residual risk of lethal collision between a vessel and a right whale associated with (a) the original and amended (solid black line) traffic separation scheme and (b) the original (solid black line) traffic separation scheme with a 10 knot speed restriction imposed over the entire study domain. Negative residuals indicate reduced risk

reduced both the vessel-whale encounter probability and the vessel risk to the whales by $90 \%$. Given the pending implementation of the IMO-adopted seasonal-recommendatory area to be avoided (ATBA) in the Roseway Basin region, similar reductions in vessel-whale encounter probabilities and risk are to be expected if vessel operators comply with the avoidance recommendation.

We can use the above risk-reduction estimate to coarsely estimate the actual number of documented lethal vessel-whale collisions that might accrue due to modified vessel-traffic patterns. Three right whale deaths were attributed to vessel strikes in the Bay of Fundy during the period 1990 though July 2003 (Knowlton \& Brown 2007); an average annual mortality rate of 0.24 (1 every $4 \mathrm{yr}$ ). A $62 \%$ reduction in this rate leads to the expectation of 0.081 lethal vessel strikes per year ( 1 every $\sim 12$ yr). Although we cannot calculate a reasonable estimate of risk reduction in the Roseway region because it is a function of unknown (at least at this time) vessel-operator compliance, we can offer similar calculations assuming a 25, 50, and $75 \%$ reduction in risk entirely attributable to modified vessel navigation. One right whale death was attributed to vessel strike in the Roseway Basin between 1990 and 2005 inclusive; corresponding to an average annual documented mortality rate of 0.063 (1 every 16 yr). Assuming a 25, 50, and $75 \%$ reduction in risk through vessel compliance the estimated number of documented lethal vessel strikes would be approximately 1 every 21, 32, and $64 \mathrm{yr}$, respectively. We emphasise that the above estimates are exceedingly conservative, as they rely only on observed (documented) lethal vessel strikes; i.e. it is estimated that only $17 \%$ of all right mortalities are observed (Kraus et al. 2005).

Technological methodologies aside (see 'Introduction'), the most pragmatic means of reducing vessel strikes to whales are to (1) reduce the probability of a vessel encountering a whale through modified vessel routing (seasonal or otherwise), (2) reduce the lethality of vessel strikes, should a collision occur, through vessel-speed restrictions, and (3) reduce overall risk through modified routing coupled with speed restrictions. In the Bay of Fundy, we have the opportunity to determine the relative merits of each of the above means of reducing risk by comparing standardised risk estimates based on Eqs. (4) \& (6) above, and by constraining the average vessel speed in a grid-cell to a maximum of 10 knots $\left(18.5 \mathrm{~km} \mathrm{~h}^{-1}\right)$.

Relative to the original TSS, the amended TSS provides an overall risk reduction of $62 \%$ (Fig. 6a, Table 2), whereas a maximum $10 \mathrm{knot}\left(18.5 \mathrm{~km} \mathrm{~h}^{-1}\right)$ speed restriction over the entire study domain results in a risk reduction of $52 \%$ (Fig. 6b, Table 2). The amended TSS provides a $10 \%$ greater reduction in the overall relative risk than would speed restrictions implemented throughout the domain, especially within the Conservation Area, and it has a lower impact on transit times for vessels navigating throughout the Fundy domain. The outbound lane of the amended TSS is $\sim 0.8 \mathrm{n}$ miles $(1.5 \mathrm{~km})$ longer than the original 
Table 2. Per cent reduction in overall risk of lethal vessel collisions to North Atlantic right whales estimated for various modified vessel-traffic options in the Bay of Fundy relative to the original (prior to 1 July 2003) traffic separation scheme (TSS)

\begin{tabular}{|lcc|}
\hline Modified vessel-traffic options & $\begin{array}{c}\text { \% reduction in overall risk } \\
\text { Entire } \\
\text { domain }\end{array}$ & $\begin{array}{c}\text { Conservation } \\
\text { Area }\end{array}$ \\
\hline Amended TSS & 62 & - \\
Speed $\leq 10$ knots $\left(18.5 \mathrm{~km} \mathrm{~h}^{-1}\right)$ & 52 & 7.5 \\
Amended TSS and speed $\leq 10$ knots $\left(18.5 \mathrm{~km} \mathrm{~h}^{-1}\right)$ & 75 & 69 \\
\hline
\end{tabular}

tion in risk. For example, other large whales including humpback, fin Balaenoptera physalus, sei B. borealis and minke frequent the Bay of Fundy and generally reach maximum abundance during the July to September period (Gaskin 1983). However, traffic-routing amendments designed to protect the right whale should not have negative consequences on the other whale species, especially if they are not sympatric with the right whales. Thus, the probability of

lane, and based on a $12 \mathrm{knot}\left(22.2 \mathrm{~km} \mathrm{~h}^{-1}\right)$ average vessel speed (Table 1), the increased length of the lane amounts to a 4 min increase in lane-transit time. This $1.4 \%$ increase in transit time achieves a $62 \%$ reduction in risk. Furthermore, it takes less time $(\sim 5 \mathrm{~h})$ for a vessel to transit the amended outbound lane at the $12 \mathrm{knot}$ $\left(22.2 \mathrm{~km} \mathrm{~h}^{-1}\right)$ average speed than it would for a vessel to transit the original lane under a $10 \operatorname{knot}\left(18.5 \mathrm{~km} \mathrm{~h}^{-1}\right)$ speed restriction $(\sim 6 \mathrm{~h})$.

If the speed restrictions were applied only to the part of the original TSS-lanes that intersects the Conservation Area, a small reduction (7.5\%) in relative risk is achieved although there is at least a $16 \mathrm{~min}(20 \%)$ increase in transit time (10 vs. 12 knots, 18.5 vs. $22.2 \mathrm{~km} \mathrm{~h}^{-1}$ ). Thus, in the Bay of Fundy, a modified routing accrues much greater risk reduction than does a $10 \mathrm{knot}\left(18.5 \mathrm{~km} \mathrm{~h}^{-1}\right)$ speed limitation. The last option of a combined TSS amendment and a $10 \mathrm{knot}(18.5 \mathrm{~km}$ $\mathrm{h}^{-1}$ ) speed restriction over the entire study domain provides a relative risk reduction of $75 \%$ compared to the $62 \%$ achieved via the 2003 TSS amendment alone, though at considerable time/speed costs and a limited reduction of risk from those vessels navigating well outside the Conservation Area. If the $10 \mathrm{knot}(18.5 \mathrm{~km}$ $\mathrm{h}^{-1}$ ) speed restriction was applied only to the amended TSS routing within the Conservation Area, the relative risk reduction would be $69 \%$, a marginal increase over the $62 \%$ above. In summary, the greatest reduction in risk of lethal vessel-strikes to right whales in the Bay of Fundy would be achieved by reducing the vessel speeds to 10 knots $\left(18.5 \mathrm{~km} \mathrm{~h}^{-1}\right)$ or less while navigating through the region in conjunction with the amended TSS. However, the least time-cost to shipping interests is associated with the small change in navigation that results from the amended TSS that achieves reduced vessel-whale encounter probabilities.

The TSS amendment in the Bay of Fundy was implemented to reduce risk to right whales in the Grand Manan Basin where they are most concentrated during summer and autumn. Consequently, other large whales inhabiting the same region also accrue a reduc- observing one of these other species in a given area may be very different from that for right whales. We therefore used the methods described above along with the SPUE data for fin, sei, humpback, and minke whales to estimate the risk to these species posed by vessels over the entire study domain in terms of the original and amended TSS. For each species the TSS amendment achieved a decrease in overall risk; $28 \%$ for minke, $27 \%$ for fin, $17 \%$ for sei, and $9 \%$ for humpback whales. Thus, the TSS amendment in the Bay of Fundy decreased the relative risk from vessels to virtually all large whales that frequent the Bay.

The vessel-traffic patterns in the Roseway Basin region are quite different from those in the Bay of Fundy, primarily due to the TSS in the latter. There are emergent traffic-lanes in the Roseway Basin domain with the most concentrated traffic transiting north of the Conservation Area and less concentrated traffic transiting in a NE↔SW direction through the Conservation Area and navigating at higher average speeds. Due to differences in the nature of the vessel data, the relative probabilities of observing vessels cannot be directly compared between the Bay of Fundy and Roseway Basin domains. However, by standardising the relative encounter and risk probabilities (Eqs. 4 \& $6)$ we can compare the 2 regions.

Prior to the TSS amendment, the relative encounter probability over the Fundy study domain was greater than over the Roseway domain by a factor of 3.0. After the TSS amendment this factor decreased to 1.7. Prior to the TSS amendment, the relative risk associated with the right whale Conservation Area in Fundy was 7.0-fold greater, on average, than the relative risk in the right whale Conservation Area on Roseway. After the TSS amendment this factor decreased, on average, to 1.7 .

Although there is no TSS in the Roseway Basin region, a seasonal (June through December) recommendatory area to be avoided (ATBA, Fig. 5e) has been proposed (IMO 2007a), approved (IMO 2007b) and will be implemented on 1 May 2008. The designation of the ATBA has been achieved, in part, because 
of the analyses provided above. The IMO-sanctioned vessel-avoidance scheme can reduce the probability of vessel encounters with right whales and can reduce the risk of lethal vessel-collisions without the imposition of speed restrictions. The magnitude of the risk reduction will be a function of vessel operator compliance. As compliance with the Roseway ATBA is recommendatory (voluntary), we cannot, at this time, easily estimate what the actual reduction might be. We could make calculations based on various anticipated area avoidance and compliance scenarios, but suffice to say that compliance by a large proportion of the transiting fleet will result in a substantial reduction in risk given that the ATBA completely surrounds the region of highest probability of encountering a right whale (cf. Fig. 5c). We can anticipate a high degree of compliance based on the assumption that most vessels transiting the Conservation Area in a NE $\leftrightarrow \mathrm{SW}$ direction at a 14 knot $\left(26 \mathrm{~km} \mathrm{~h}^{-1}\right)$ average speed (see Fig. 5b,d) will comply, given the small adjustment in routing and travel time if avoidance-routing is planned ahead of time. For example, if vessels normally navigating either SW from Halifax or NE from the New York City TSS (thus in the diagonal traffic pattern illustrated in Fig. 5b,d) were to adjust their heading by $7^{\circ}$ (SW or NE as required) at a point some $93 \mathrm{n}$ miles $(172 \mathrm{~km})$ either side of the ATBA boundary, they would transit just outside of the SW corner of the ATBA and the route would be $2 \mathrm{n}$ miles $(3.7 \mathrm{~km})$ longer than their normal $226 \mathrm{n}$ miles $(419 \mathrm{~km})$ route. At an average speed of 14 knots $\left(26 \mathrm{~km} \mathrm{~h}^{-1}\right)$ the increase in transit time would amount to $8.6 \mathrm{~min}$ over the now $228 \mathrm{n}$ miles $(422 \mathrm{~km})$ route. If a $10 \mathrm{knot}\left(18.5 \mathrm{~km} \mathrm{~h}^{-1}\right)$ speed restriction was imposed for vessels inside and transiting the Conservation Area along the diagonal traffic pattern (as opposed to an ATBA), then the normal transit time of $2.3 \mathrm{~h}$ at an average 14 knots $\left(26 \mathrm{~km} \mathrm{~h}^{-1}\right)$ would increase by $40 \%$ to $3.2 \mathrm{~h}$. As in the Bay of Fundy, rerouting of vessels in this region comes with lower costs to vessel operators than would a $10 \mathrm{knot}(18.5 \mathrm{~km}$ $\mathrm{h}^{-1}$ ) speed restriction, while at the same time substantially reducing risk to the whales. A 10 knot $(18.5 \mathrm{~km}$ $\mathrm{h}^{-1}$ ) speed restriction within the Conservation Area could serve as an incentive for vessel operators to comply with the ATBA.

To reduce the risk to whales, the goals of ATBAs, amended TSSs and/or speed restrictions should be to achieve the greatest reduction in risk balanced by some minimal disruption to vessel operations while maintaining safe navigation. Although Elvin \& Taggart (2008) argue that mitigating encounters between large vessels and right whales may be difficult, we have shown it is feasible where the data are available. Statistical and probabilistic methods can be used to achieve the above goals, as we have shown.
Our analyses rely on the temporally aggregated SPUE and vessel data that do not incorporate the daily, seasonal and interannual viability in whale distributions and vessel-traffic patterns, and we are thus assuming that the spatial probabilities associated with both the whales and the vessels in either habitat area remain stable. If measures are to be implemented to protect whales (or other marine animals), designing modifications to traffic patterns could be seasonally based as is the case for the ATBA in Roseway Basin; annually for the June through December period. However, if seasonal and/or interannual temporal variability in animal distributions is large, then risk reduction may require year-round implementation of traffic restrictions.

The methods presented here are used to quantify relative encounter probabilities and relative risk to North Atlantic right whales from ocean-going vessels. They also provide a means of estimating reductions in relative encounter probabilities associated with the various options available to reduce risk. Speed restrictions and areas to be avoided are being proposed in the United States of America (NOAA 2006, Merrick \& Cole 2007) and elsewhere, and such analyses can be used to directly assess the utility of re-routing, speed restrictions or both.

Acknowledgements. We thank the New England Aquarium, the North Atlantic Right Whale Consortium and the many staff and volunteers who collected survey data, F. Webster and D. Edmonds (MCTS Saint John, New Brunswick) and G. Herbert (Oceans and Coastal Management Division, Fisheries \& Oceans Canada) for data access. We are grateful for funding in support of the various initiatives addressed in the paper; funds were provided by S. Haney and the Canadian Whale Institute, the Environment Canada Habitat Stewardship Programme, the World Wildlife Fund Canada and Environment Canada Endangered Species Research Fund, Fisheries \& Oceans Canada (St. Andrews Biological Station and the Oceans and Coastal Management Division) and the Natural Sciences and Engineering Research Council of Canada. We thank J. Beaudin Ring, D. Gillis, N. Helcl, J. Mullarney, A. Neuheimer, R. Pelot, B. Smith, C. C. Smith, and 2 anonymous referees for advice, critiques and assistance.

\section{LITERATURE CITED}

Baumgartner MF, Mayo CA, Kenney RD (2007) Enormous carnivores, microscopic food, and a restaurant that's hard to find. In: Kraus SD, Rolland RM (eds) The urban whale: North Atlantic right whales at the crossroads. Harvard University Press, Cambridge, MA, p 138-171

Brown MW, Allen JM, Kraus SD (1995) The designation of seasonal right whale conservation areas in the waters of Atlantic Canada. In: Shackell NL, Willison JHM (eds) Marine protected areas and sustainable fisheries. Science and Management of Marine Protected Areas Association, Wolfville, NS, p 90-98 
Brown MW, Kraus SC, Slay CK, Garrison LP (2007) Survey for discovery, science, and management. In: Kraus SD, Rolland RM (eds) The urban whale: North Atlantic right whales at the crossroads. Harvard University Press, Cambridge, MA, p 105-137

Campbell-Malone R, Barco SG, Daoust PY, Knowlton AR, McLellan WA, Rotstein DS, Moore MJ (2008) Gross and histologic evidence of sharp and blunt trauma in North Atlantic right whales (Eubalaena glacialis) killed by vessels. J Zoo Wildl Med 39:37-55

Canada Shipping Act (1985) R.S., 1985, c.S-9; 2001, c.26 Regulatory Reform. Act repealed 01 July 2007 in accord with SI/2007-65, 27 June, 2007. Canada Gazette Part II, Volume 141, No. 10, 16 May 2007, Ottawa

Caswell H, Fujiwara M, Brault S (1999) Declining survival probability threatens the North Atlantic right whale. Proc Natl Acad Sci USA 96:3308-3313

CETAP (Cetacean and Turtle Assessment Program) (1982) A characterization of marine mammals and turtles in the mid- and North Atlantic areas of the U.S. outer continental shelf. Final Report of the Cetacean and Turtle Assessment Program to the U.S. Department of the Interior, Washington, DC. Contract AA5551-CT8-48

Clark CW, Gillespie D, Nowacek DP, Parks SE (2007) Listening to their world: acoustics for monitoring and protecting right whales in an urbanized ocean. In: Kraus SD, Rolland RM (eds) The urban whale: North Atlantic right whales at the crossroads. Harvard University Press, Cambridge, MA, p 333-357

Corbett JJ (2004) Marine transportation and energy use. In: Cleveland CJ (ed) Encyclopedia of energy, Vol 3. Elsevier Science, San Diego, CA, p 745-748

Corbett JJ, Koehler HW (2003) Updated emissions from ocean shipping. J Geophys Res 108(D20):4650-4666

Culik BM, Koschinski S, Tregenza N, Ellis GM (2001) Reactions of harbor porpoises Phocoena phocoena and herring Clupea harengus to acoustic alarms. Mar Ecol Prog Ser 211:255-260

Elvin S, Taggart CT (2008) Right whales and vessels in Canadian waters. Mar Pol 32:379-386

Fujiwara M, Caswell H (2001) Demography of the endangered North Atlantic right whale. Nature 414:537-541

Gaskin DE (1983) The marine mammal community. In: Thomas MLH (ed) Marine and coastal systems of the Quoddy region, New Brunswick. Can Spec Pub Fish Aquat Sci 64, p 245-268

Gaskin DE (1987) Updated status of the right whale, Eubalaena glacialis, in Canada. Can Field Nat 101:295-309

IMO (International Maritime Organization) (2003) New and amended traffic separation schemes. REF T2/2.07, COLREG.2/Circ.52. IMO, London

IMO (International Maritime Organization) (2007a) Routing of ships, ship reporting, and related matters. NAV 53/3/13, IMO, London

IMO (International Maritime Organization) (2007b) Routing measures other than Traffic Separation Schemes. Ref. T2OSS/2.7, SN.1/Circ.263, IMO, London

IWC (International Whaling Commission) (2001) Report of the workshop on status and trends of western North Atlantic right whales. J Cetacean Res Manag 2(Spec Issue):61-87

Kenney RD (2001) The North Atlantic Right Whale Consortium databases. Maritimes 43:3-5

Kenney RD, Mayo CA, Winn HE (2001) Migration and foraging strategies at varying spatial scales in western North Atlantic right whales: a review of hypotheses. J Cetacean Res Manag 2(Spec Iss):251-260
Knowlton AR, Brown MW (2007) Running the gauntlet: right whales and vessel strikes. In: Kraus SD, Rolland RM (eds) The urban whale: North Atlantic right whales at the crossroads. Harvard University Press, Cambridge, MA, p 409-435

Knowlton AR, Kraus SD (2001) Mortality and serious injury of northern right whales (Eubalaena glacialis) in the western North Atlantic Ocean. J Cetacean Res Manag 2(Spec Issue):193-208

Knowlton AR, Kraus SD, Kenney RD (1994) Reproduction in North Atlantic right whales (Eubalaena glacialis). Can J Zool 72:1297-1305

> Kraus SD (1990) Rates and potential causes of mortality in North Atlantic right whales (Eubalaena glacialis). Mar Mamm Sci 6:278-291

Kraus SD, Rolland RM (2007) Right whales in the urban ocean. In: Kraus SD, Rolland RM (eds) The urban whale: North Atlantic right whales at the crossroads. Harvard University Press, Cambridge, MA

$>$ Kraus SD, Read AJ, Solow A, Baldwin K, Spradlin T, Anderson E, Williamson J (1997) Acoustic alarms reduce porpoise mortality. Nature 388:525

Kraus SD, Hamilton PK, Kenney RD, Knowlton AR, Slay CK (2001) Reproductive parameters of the North Atlantic right whale. J Cetacean Res Manag 2(Spec Iss):231-236

Kraus SD, Brown MW, Caswell H, Clark CW and others (2005) North Atlantic right whales in crisis. Science 309:561-562

> Laurinolli MH, Hay AE, Desharnais F, Taggart CT (2003) Localization of North Atlantic right whale sounds in the Bay of Fundy using a sonobuoy array. Mar Mamm Sci 19:708-723

Matthews JN, Brown S, Gillespie D, Johnson M and others (2001) Vocalisation rates of the North Atlantic right whale (Eubalaena glacialis). J Cetacean Res Manag 3:271-282

> Mellinger DK, Nieukirk SL, Matsumoto H, Heimlich SL and others (2007) Seasonal occurrence of North Atlantic right whale (Eubalaena glacialis) vocalizations at two sites on the Scotian Shelf. Mar Mamm Sci 23:856-867

Merrick RL, Cole TVN (2007) Evaluation of northern right whale ship strike reduction measures in the Great South Channel of Massachusetts. NOAA Tech Memo NMFSNE-202, p 1-12

Michaud J, Taggart CT (2007) Lipid and gross energy content of North Atlantic right whale food, Calanus finmarchicus, in the Bay of Fundy. Endang Species Res 3:77-94

Moore MJ, McLellan WA, Daoust PY, Bonde RK, Knowlton AR (2007) Right whale mortality: a message from the dead to the living. In: Kraus SD, Rolland RM (eds) The urban whale: North Atlantic right whales at the crossroads. Harvard University Press, Cambridge, MA, p 358-379

NARWC (North Atlantic Right Whale Consortium) (2005) North Atlantic Right Whale Consortium sightings database, 02 March 2005. New England Aquarium, Boston, MA

NOAA (National Oceanic and Atmospheric Administration) (2006) Proposed rule to implement speed restrictions to reduce the threat of ship collisions with North Atlantic right whales. Fed Regist 71:36299-36319

> Nowacek DP, Johnson MP, Tyack PL (2004) North Atlantic right whales (Eubalaena glacialis) ignore ships but respond to alerting stimuli. Proc R Soc Lond Ser B Biol Sci 271:227-231

Panigada S, Pesante G, Zanardelli M, Capoulade F, Gannier A, Weinrich MT (2006) Mediterranean fin whales at risk from fatal ship strikes. Mar Pollut Bull 52:1287-1298 
Rosenbaum HC, Brownell RL, Brown MW, Schaeff C and others (2000) World-wide genetic differentiation of Eubalaena: questioning the number of right whale species. Mol Ecol 9:1793-1802

Scott GP, Gilbert JR (1982) Problems and progress in the US BLM-sponsored CETAP surveys. Rep Int Whaling Comm 32:587-600

Stone GS, Kraus SD, Prescott JH, Hazard KW (1988) Significant aggregations of the endangered right whale, Eubalaena glacialis, on the continental shelf of Nova Scotia. Can Field Nat 102:471-474

Todd S, Lien J, Verhulst A (1992) Orientation of humpback whales (Megaptera novaeangliae) and minke whales (Balaenoptera acutorostrata) to acoustic alarm devices designed to reduce entrapment in fishing gear. In: Thomas JA, Kastelein RA, Supin AY (eds)

Editorial responsibility: Wayne Linklater,

Wellington, New Zealand
Marine mammal sensory systems. Plenum, New York, p 727-739

Trippel EA, Strong MB, Terhune JM, Conway JD (1999) Mitigation of harbour porpoise (Phocoena phocoena) by-catch in the gillnet fishery in the lower Bay of Fundy. Can J Fish Aquat Sci 56:113-123

Vanderlaan ASM, Taggart CT (2007) Vessel collisions with whales: the probability of lethal injury based on vessel speed. Mar Mamm Sci 23:144-156

Vanderlaan ASM, Hay AE, Taggart CT (2003) Characterization of North Atlantic right-whale (Eubalaena glacialis) sounds in the Bay of Fundy. IEEE J Ocean Eng 28:164-173

Waldick RC, Kraus S, Brown M, White BN (2002) Evaluating the effects of historic bottleneck events: an assessment of microsatellite variability in the endangered, North Atlantic right whale. Mol Ecol 11:2241-2249

Submitted: November 1, 2007; Accepted: January 31, 2008 Proofs received from author(s): March 21, 2008 